\begin{tabular}{lc|}
\hline \hline \hline & International Journal of Current Research \\
& and Academic Review \\
EXCELLENT \\
PUBLISHERS
\end{tabular}

doi: https://doi.org/10.20546/ijcrar.2018.605.005

\title{
Review on Onion Value Chain Analysis in Ethiopia
}

\author{
Agidew Abebe* \\ University, Arba Minch, Ethiopia \\ *Corresponding author

\begin{abstract}
Onion (Alluim copa) is one of the most important commercial vegetable and it is cool seasonal vegetables. Onion production has a significant role in reducing poverty through employment generation, improving the feeding behavior of the people, and creating new opportunities for poor farmers. The general objective of the study is to analyze the value chains of onion in the study areas. With specific objectives of, to identify the opportunities and constrains of onion production and marketing in the study area. To analyze the channel of onion marketing in the study area, and to identify the main value chain actors.
\end{abstract}

Department of Rural Development and Agricultural Extension, College of Agricultural Science, Arba Minch

\section{Article Info}

Accepted: 20 April 2018

Available Online: 20 May 2018

\begin{tabular}{l} 
Keywords \\
\hline Onion value; \\
Chain analysis; \\
onion marketing; \\
Value chain actors
\end{tabular}

\section{Introduction}

Onion (Alluim copa) is one of the most important commercial vegetable. Onion is cool seasonal crop. However, it can be grows under wide range of climate conditions. It grows well under mild climate without extreme heat or cold or excessive rainfall. The principal alliums rank second in value after tomatoes -on list of cultivated vegetable crops worldwide (Robbin with and Cur rah, 2012). These people also reminded that all plant parts of alliums may be consumed by humans (except perhaps the seed), and many wild species are exploited by local in habitants. Careful handling and the choice of suitable storage method for the cultivar type in question are vital to insure that the product retain its quality until it reaches the consumer. "Cosmetic quality is of increasing importance in competitive market. The product is produced both consumption and market.
According to CSA (2010) out of a year productive, 48.2 percent was utilized for sale, 39.9 percent for house hold consumption in construct to tomatoes where 66.7 percent of the total production is send to market.

According to lemma and Shimeles, small farmers, private growers, state enterprise mainly in awash valley and Lake Region produce 2003, in Ethiopia onion in many parts of the country while the bulk of dry bulbs and seed are produced.

Recent statically data (CSA, 2010) indicated the total hectare under onion was about 20,444 hectare with total production of 2,572,053 quintals dry bulbs per annum. Globally onion is produce to, at nearly 35 million meters per annum (FAO, 2011). However, despite the enormous merits and potential, in Ethiopia the existing crop productivity has been low and variable under farmers' 
local condition. This is presumably due to lock of improved crop verities, shortage adapted varies to different agro-ecologies lack of input, lack of appropriate agronomic package, disease and poor extension activities.

\section{Development of market-driven onion value chain}

The value chain approach considers both the benefit of a product and an insight into the actors' roles and relations. The value chain approach analyses a product's development process from input supply through production and processing level, transport, trade and marketing, to consumption. Despite the fact that, earlier work on agriculture concentrated mainly on improving the supply side of the respective value chains e.g. production 18 conditions and output, recent studies have also paid attention to the demand side (Diao, 2011). Here the value chain analysis concentrates on both ends of the chain corresponding with the two sides of a market

The development of the domestic markets of onion is strongly determined by factors on the supply side; example soils, aridity, agricultural knowledge, competition, weather, and market infrastructure as well as on the demand side example increase in population, urbanization, and income-elasticity. As onion are highly perishable commodities there are many difficulties during the marketing process. Natural occurrences such as aridity, the composition of soils, and the weather are mainly responsible for creating opportunities and constraints on the supply side of the market. Seasonality strongly influences the supply side of the onion production.

Production of onion in rain fed is highly affected by seasonality (high and low supply on the markets), which is mainly influenced by the climate and weather conditions. Those farmers who have access to irrigation can operate more independently of the seasons (Koenig et al., 2008). Furthermore, the importance of market coordination and market participation have been highlight and describe as one of the most important constraints responsible for the poor performance of onion (Dorward et al., 2009). According to estimations by Kelley and Byerlee (2010) some $60 \%$ of the African rural population lives in areas of good agricultural potential, but with poor market access. Only $22 \%$ live in areas of good agricultural potential and good market access and 18\% suffer from poor market access and poor agricultural potential

\section{Properties of onion marketing}

Onion market influents by numbers of factors that can be to production product and market characteristics of onion marketing.

Perishability as onion are highly perishable, they start to close their quality right after harvested continued throughout the process until is it consumed, for this purpose elaborated and extensive marketing channels facilities and equipments vital.

Price/quality risk the crops were subjected to high price and quantity risk with changing consumer, demands and production conditions. Unusual production or harvesting weather or major crop disease can influence badly the marketing system.

Seasonality onions have seasonal production directly influencing their marketing. Normally they have limited period harvest and more or less a year round demand.

Product bulkiness water is a major component of the product hence it makes them bulky and low value per unit that is expensive to transport in fresh from every large time. This, therefore, exposed farmers to lose large amount of product in the farm unsold.

\section{Empirical studies}

The behavior of marketed surplus to changes in prices and non-price factors like irrigation, acreage and productivity is of critical importance. The most important factor, which increases marketed surplus significantly, is the increased production or output followed by consumption and payments in kind which should be reduced to keep up the quantity of marketed surplus of food grains (Thakur et al., 2009).

A study conducted by Moraket (2011) indicated that households participating in the market for horticultural commodities are considered to be more commercially inclined due to the nature of the product. Horticulture crops are generally perishable and require immediate disposal. As such, farmers producing horticulture crops do so with intent to sell. In his study it was found that $19 \%$ of the sample households are selling all or a proportion of their fruits and vegetable harvest to a range of market outlets varying from informal markets to the large urban based fresh produce markets. Typically, many of the households producing fruits and vegetables also have 
access to a dry land plot where they commonly produce maize and/or other filed crops Bezabih and Hadera (2010), in their research identified pest, drought, shortage of fertilizer, and price of fuel for pumping water as the major constraints of horticulture production in Eastern Ethiopia. Other problems which they reported also include poor know how in product sorting, grading, packing, and traditional transporting affecting quality.

According to Moti (2011) a farm gate transaction usually happens when crops are scarce in their supply and highly demanded by merchants or when the harvest is bulk in quantity and inconvenient for farmers to handle and transport to local markets without losing product quality. For crops like tomato, farm gate transactions are important as grading and packing are done on the farm under the supervision of the farmer. Therefore, households were expected to base their crop choice on their production capacity, their ability to transport the harvest themselves and their preferred market outlet.

A study conducted by Bossena (2008) cotton marketing in Metemaworeda identified that four variables affect cotton marketable supply. Owen oxen number, access to credit, land allocated to cotton, productivity of cotton in 2005/06 were the variables affecting positively cotton supply.

Similar study on sesame at Metema by Kinde (2007) also pointed out six variables that affect sesame marketable supply. Yield, oxen number, foreign language spoken, modern input use, area, time of selling were the variables affecting positively sesame supply and unit cost of production was found to negatively influence the supply. Similarly, Abay (2007) in his study of vegetable market chain analysis identified variables that affect marketable supply.

According to him, quantity production and total area owned were significant for onion supply but the sign for the coefficient for total area of land was Negative. For tomato supply, quantity of production, distance from Wrote and labor were significant. Similarly, Rehima (2007) in her study of pepper marketing chain analysis identified variables that affect marketable supply. According to her, access to market, production level, extension contact, and access to market information were among the variables that influence surplus.

\section{Actors and their role in onion value chain}

The value chain map highlighted the involvement of diverse actors who are participated directly or indirectly in the value chain. According to KIT et al. (2009), the direct actors are those involved in commercial activities in the chain (input suppliers, producers, traders, consumers) and indirect actors are those that provide financial or non-financial support services, such as credit agencies, business service providers, government, NGOs, cooperatives, researchers and extension agents.

\section{Primary actors}

The primary actors in onion value chain in Arbaminchzuria Woreda were seed and other input suppliers, farmers, traders and consumers. Each of these actors adds value in the process of changing product title. Some functions or roles are performed by more than one actor, and some actors perform more than one role.

\section{Input suppliers}

At this stage of the value chain, there are many actors who are involved directly or indirectly in agricultural input supply in the study area. Currently OoARD, primary cooperatives/ union and private input suppliers are the main source of input supply. Onion growing farmers also participated in this stage. All such actors are responsible to supply agricultural inputs like improved seed varieties, fertilizers, herbicides, pesticides and farm implements which are essential inputs at the production stage. For major onion produced in Arbaminchzuria Woreda, the majority of the sample producers used their own seed. Regarding fertilizers, some farmers used only organic fertilizer (manure and compost) while some farmers used both inorganic and organic fertilizers depending on the land size allocated to production, onion type produced and the soil fertility status as perceived by the farmers. Pesticides are supplied mostly by private vendors.

\section{Producers}

Onion growers are the major actors who perform most of the value chain functions right from farm inputs preparation on their farms or procurement of the inputs from other sources to post harvest handling and marketing. The major value chain functions that onion growers perform include ploughing, planting, fertilization, irrigating, weeding, pest/disease controlling, harvesting and postharvest handling. 
The diverse agro-climatic conditions can make growing onion crops highly cost-effective and competitive, and provide vast opportunities in study areas. Unfortunately, these opportunities have not been exploited by the farmers due to the lower price they receive for their produce in the markets, as well as bearing the cost of post-harvest losses. Onion production in this Woreda was based on rain fed and in small amount irrigation system. Postharvest handling, which includes different activities like sorting, grading, packing, storing, transportation, loading and unloading, is done by the farmers themselves or traders). There are high postharvest losses due to improper harvesting, handling, packaging and poor facilities to market. Means of transportation varies among producers to producers but predominately producers use pack animals and vehicles.

\section{Collectors/Assemblers}

These are traders in assembly markets who collect onions from farmers in village markets and from farms for the purpose of reselling it to wholesalers and retailers. They use their financial resources and their local knowledge to bulk onion from the surrounding area. They play important role and they do know areas of surplus well. The trading activities of collectors include buying and assembling, repacking, sorting, transporting and selling to wholesale markets retailers, as well as consumers.

\section{Wholesalers}

Wholesalers are mainly involved in buying onion from collectors and producers in larger volume than any other actors and supplying them to retailers and consumers. They also store product, usually for a maximum of three days. Survey result indicates that wholesale markets are the main assembly centers for onion in the surrounding areas. They have better storage, transport and communication access than other traders. Almost all wholesalers have a warehouse in a market either selfowned or rental basis. They are located in market.

\section{Retailers}

Retailer involvement in the chain includes buying of onion, transport to retail shops, grading, displaying and selling to consumers. Retailers are key actors in onion value chain in both. They are the last link between producers and consumers. They mostly buy from wholesalers and sell to urban consumers. Sometimes they could also directly buy from the producers.
Consumers usually buy the product from retailers as they offer according to requirement and purchasing power of the buyers.

\section{Onion consumers}

Consumers are those purchasing the products for consumption. About two types of onion consumers were identified: households and, restaurants. Private consumers purchase onion directly from producers, retailers and wholesalers though most of the consumers purchase from retailers. Farmers also make important segment of the rural consumers since they consume part of their produces.

Consumers prefer medium size, circle shape, red color, strong, dray and free from damage onion. In general consumers have their own quality criteria to purchase vegetables.

\section{Production and marketing constraints and opportunities}

Problems stretched from input supply late to marketing. Understanding problems and opportunities with priorities was very important for both research and development initiatives. A number of production and marketing problems as well as opportunity of production and marketing were identified in this study and the following problems were identified in order of importance. For sake of clear understanding problems are divided into marketing and production problems.

\section{Production constraints}

Poor product handling- Absence of appropriate postharvest handling practice reduces the farmers' product quality. The price of the perished product is low even it may be not sold. Deteriorate vegetables can cause disease to human being if it is eaten. To protect these and other problems the farmers should keep the quality of their products'.

Pest and disease- Problem of pest and disease like root rot. Limited production and marketing extension supportEven though there seem sufficient number of development agents deployed in each Kebele they lacked then Competence on pre-and postharvest handling practices. It was for this fact that farmers applied much seed rate above the recommendation, watered the field at harvest, and did not store. 
Unorganized input delivery- farmers used to get seeds from open market. There were no certification, quality test, and failure guarantees. As a result, farmers faced problems of seed viability.

\section{Marketing constraints}

Imperfect pricing system- Frequent low price at peak supply periods that based not the real supply and demand interaction but the information collusion and gang up between buying participants. The intermediaries used to decide on the price of onion products. Wholesalers were mostly the beneficiaries and they controlled and regulated the chain.

Absence of law enforcement on standards- The prevalence of strong and wide market cheating by wholesalers and relaters like miss-weighing, collusion (low price quotation, price information). There were no identified and applied quality standards that resulted in absence of discriminatory pricing accounting for quality and grades.

Lack of coordination among producers- Farmers were not coordinated to increase their bargaining power. There was no any marketing institution to safeguard farmer's interest and rights over their marketable produces. Even the existing few irrigation cooperatives lacked skill and capacity on how to go about. Rather, competition among farmers was the usual phenomenon.

Lack of improvement for other actors in the channelLimited attention was given too there parts of the channel, like lack of attention for retailers in improving the stalls that had very right effect on the shelf life of the products. And other marketing problems identified in this study was lack of credit lack of demand, quality problem, information gap, lack of storage material and supply shortage of input are some problems that face traders.

\section{Production opportunities}

Availability of rain fall, facilitate the production of onion in generating income in short period, its better productivity in small land, its use as cash income source or livelihood consumption, increasing price and its continuous demand in the market were some of the opportunities of onion by most of the producers. The survey result shows that most of the producers intend to expand onion production due to the above opportunities.
The Woredas are also naturally endowed though they have some production and marketing opportunity. Some of the potentials to mention are the following. The Woredas are very suitable to produce not only onion products but also other market oriented commodities. Of the potential crops, tropical fruits like, mango, banana, orange and avocado; production are some of the available potentials. On top of this, relatively fertile arable land and abundant weather condition potential are some to mention. Government suitable agricultural policies designed to support farmers at the grass-root level especially emphasis given for horticultural production in Growth and Transformation Plan (GTP) is the other opportunity dimension. The deployment of development agents at each kebeles based on their academic back ground are also important policy dimensions. Furthermore, provision of infrastructure facilities like roads, telecommunication, power supply and financial institutions are the infrastructural advantages that facilitate the production and marketing of vegetables in the study area.

\section{Marketing opportunities}

On the other hand, availability of market demand throughout the year, growing number of buyers, high experience in onion trade and growing price were some of the opportunities of onion by most of the producers. The study result shows that of the producers intended to expand onion due to the above opportunities. The Woreda was not only with problems but it had also opportunities, the trend in the growth of production and marketing tradition in the area was one that drew attention. Availability of market demand throughout the year, growing number of buyers, high experience in onion trade and growing price were some of the opportunities by most of the producers. The natural advantage of proximity to air condition and availability of rain throughout the year are still the opportunities, which could facilitate commercialization in the Woreda. The existence of good policy framework in agricultural development manifested by employing development agents at each Kebele, and infrastructure development could facilitate onion production and marketing. The increasing use of mobile telephone and wireless telephone are also the other infrastructural advantages to improve system.

\section{References}

AbayAkalu, 2007. Vegetable Market Chain Analysis in Amhara National Regional State: Thecase 
of Fogeraworeda, south Gondar. An MSc thesis presented to the school of graduate studies of Haramaya University,Etiopia.pp99.

Bezabih, E., and Hadera, G., 2010. Constraints and opportunities of horticulture production and marketing in eastern Ethiopia. Dry Lands Coordination Group Report No 46. Grensen9b. Norway. 90

BossenaAlemayehu, 2008. Cotton market chain analysis: The case of Metemaworeda, north Gonder zone: Amhara National Regional State. MSc thesis presented to the School of Graduate Studies of Haramaya University, Ethiopia.

CSA (Central Statistical Authority), 2010. Area and production of major crops. Sample Enumeration Survey. Addis Ababa, Ethiopia.

FAO (food and agricultural organization), 2011, addressing marketing and processing constraints

that inhabit agro food exports: a guide for policy analysis and planners.

Globalvaluechains.org, 2011
Kinde Aysheshim., 2007. Sesame market chain analysis: The case of Metemaworeda, north Gonder zone: Amhara National Regional State. MSc thesis presented to the School of Graduate Studies of Haramaya Universi Etiopia.

MotiJaleta, 2011. Econometric analysis of horticultural production and marketing inCentral and Eastern Ethiopia. $\mathrm{PhD}$ Dissertation. Wageningen University. The Netherlands.101p. MSc thesis presented to the school of graduate studies of Haramaya University, Ethiopia.

Morkat, T., 2001. Marketing of Small holder Produce, A synthesis of case studies in the highlands of Central Kenya, English press, Kenya, Nairob

Rehima, M., 2006. Analysis of Red pepper marketing: the case of Alaba and Silte in SNNPRS

Robino with H, D and L. Currah, 2002. Alliums crop sciences recent advance, CAB. Publishing international Lando. U.K. Pp. 515.

\section{How to cite this article:}

Agidew Abebe. 2018. Review on Onion Value Chain Analysis in Ethiopia. Int.J.Curr.Res.Aca.Rev. 6(5), 21-26. doi: https://doi.org/10.20546/ijcrar.2018.605.005 